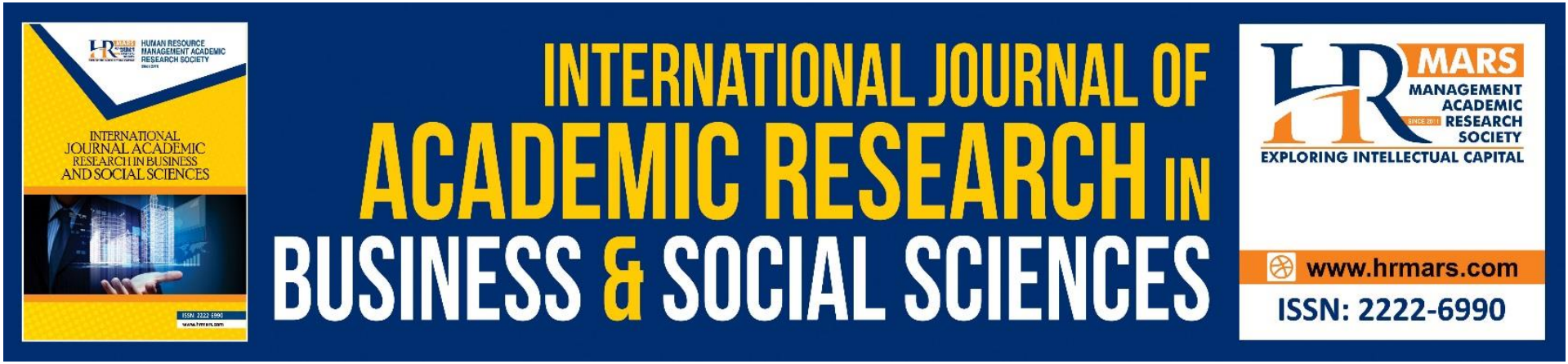

\title{
A Systematic Review: The Effect of Culturally Responsive Pedagogy on Student Learning and Achievement
}

\author{
Yong Li Wah, Nurfaradilla Binti Mohamad Nasri
}

To Link this Article: http://dx.doi.org/10.6007/IJARBSS/v9-i5/5907

DOI: $10.6007 /$ IJARBSS/v9-i5/5907

Received: 08 March 2019, Revised: 02 April 2019, Accepted: 22 April 2019

Published Online: 21 May 2019

In-Text Citation: (Wah \& Nasri, 2019)

To Cite this Article: Wah, Y. L., \& Nasri, N. B. M. (2019). A Systematic Review: The Effect of Culturally Responsive Pedagogy on Student Learning and Achievement. International Journal of Academic Research in Business and Social Sciences, 9(5), 588-596.

Copyright: (C) 2019 The Author(s)

Published by Human Resource Management Academic Research Society (www.hrmars.com)

This article is published under the Creative Commons Attribution (CC BY 4.0) license. Anyone may reproduce, distribute, translate and create derivative works of this article (for both commercial and non-commercial purposes), subject to full attribution to the original publication and authors. The full terms of this license may be seen

at: http://creativecommons.org/licences/by/4.0/legalcode

\section{Vol. 9, No. 5, 2019, Pg. 588 - 596}

Full Terms \& Conditions of access and use can be found at http://hrmars.com/index.php/pages/detail/publication-ethics 


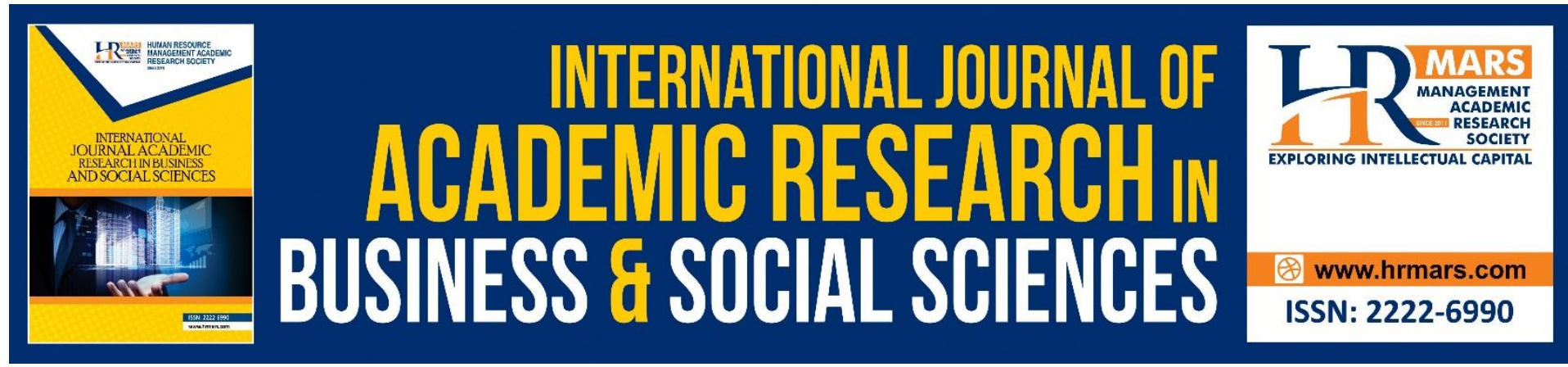

\title{
A Systematic Review: The Effect of Culturally Responsive Pedagogy on Student Learning and Achievement
}

\author{
Yong Li Wah, Nurfaradilla Binti Mohamad Nasri \\ (Faculty of Education, National University of Malaysia) \& (Senior Lecturer, Faculty of Education, \\ National University of Malaysia) \\ Email: yongliwah@gmail.com
}

\begin{abstract}
"Culturally Responsive Pedagogy" has gained increasing attention over the last two decades as a way to improve academic achievement. There are numerous studies related to this pedagogy have been conducted for various purposes. Hence, a systematic survey is conducted to gather evidence from the latest research on its impact on student learning and academic achievement through the ERIC and google scholar databases. This study is conducted to examine the effect of "Culturally Responsive Pedagogy" on students' learning where there are six articles were finally selected which meet the study' goals based on the PRISMA protocol. The findings show that this pedagogy has a positive impact in improving the involvement of students on their learning and academic achievement. Moreover, in order to strengthen the implementation of this pedagogy in learning, it is certain that reinforcement should be given to research that describes the practice and its implementation in the classroom as well as its effect on the students.
\end{abstract}

Keywords: Culturally Responsive Pedagogy, Systematic Review, Academic Achievement

\section{Introduction}

Races and ethnicity are often easily seen and scrutinized by people as well as related issues that can raise the level of self-awareness of individuals around different racial and ethnic groups (Silverman 2010). Malaysia is a country of diverse races and ethnicities. This is a privilege of this country. However, at the same time, these ethnic differences will affect the teaching and learning of students in the context of education (Hawley \& Nieto 2010).

"Culture is central to how all learning takes place" (Gay 2010). "Culturally Responsive Pedagogy" can be defined as using cultural knowledge, past experiences and student performance styles of various ethnic groups to make learning more relevant and effective to students (Gay 2010). In short, "Culturally Responsive Pedagogy" is a student centered approach that takes into account and recognizes the importance of the student's cultural background in learning. This includes the most important foundation of this pedagogy which is to ensure that students feel welcome and appreciated in the learning that takes place in the classroom.

"Culturally Responsive Pedagogy" is an effective teaching method for one classroom that consists of culturally diverse students (Irvine 2009). Recent studies have proved that "Culturally Responsive Pedagogy" is very effective in reducing the gap of academic achievement and promoting 
positive ethnic identities for different racial and ethnic groups (Dickson \& Fermandez 2015; Sleeter 2012). Besides that, there is also a study proving that the teaching of "Culturally Responsive" will encourage the involvement of students in learning and also the academic achievement of students (Christianakis 2011; Rodriguez et al. 2004).

However, research that links "Culturally Responsive Pedagogy" with its impact on student academic achievement is very small in number which only consists of case studies in small scale while many studies related to "Culturally Responsive Pedagogy" have been conducted. In conclusion, teaching students who come from a wide range of ethnic and racial backgrounds is an important thing for a multi ethnic country like Malaysia and should be the main focus in the context of education in order to develop students holistically in line with the main goal of the National Philosophy of Education in Malaysia.

Finally, "Culturally Responsive Pedagogy" is a method of teaching that has been studied by many researchers and has proven its effectiveness in the teaching and learning process. Hence, this systematic review aims to examine the effect of "Culturally Responsive Pedagogy" on the learning and academic achievement of students in school as well as current research trends on this subject.

\section{Methodology}

The PRISMA Protocol has been used in the process of selecting relevant articles. The four steps identified in the PRISMA protocol are identification, screening, eligibility and included.

The search process uses the ERIC and google scholar databases at the identification stage which is the first stage based on the PRISMA protocol. There were three key words used: culturally responsive pedagogy, culturally responsive pedagogy and student engagement, culturally responsive pedagogy and student achievement. In addition, inclusive and exclusive criteria have also been set for obtaining data that really meets the objectives of this study. The inclusive and exclusive criteria that have been used are as follows: limiting the year for article search in which searches are made only to existing articles from 2010 to 2019; search sources are a variety of journals, theses, proceedings and reports; use articles references to track and obtain articles that are relevant to the objectives of this study; only articles written in English are accepted. A total of 452 articles were found through two databases which is ERIC and goggle scholar at the initial identification stage. Although specific criteria have been set in order to search for the related articles, there are some overlapping or non-relevant results. Through several screenings, the abstracts of the articles were reviewed and then those irrelevant articles were excluded from being analyzed for this study. Overall, six relevant articles were finally selected which meet the study' goals and systematically reviewed. 
INTERNATIONAL JOURNAL OF ACADEMIC RESEARCH IN BUSINESS AND SOCIAL SCIENCES Vol. 9, No. 5, May, 2019, E-ISSN: 2222-6990 @ 2019 HRMARS

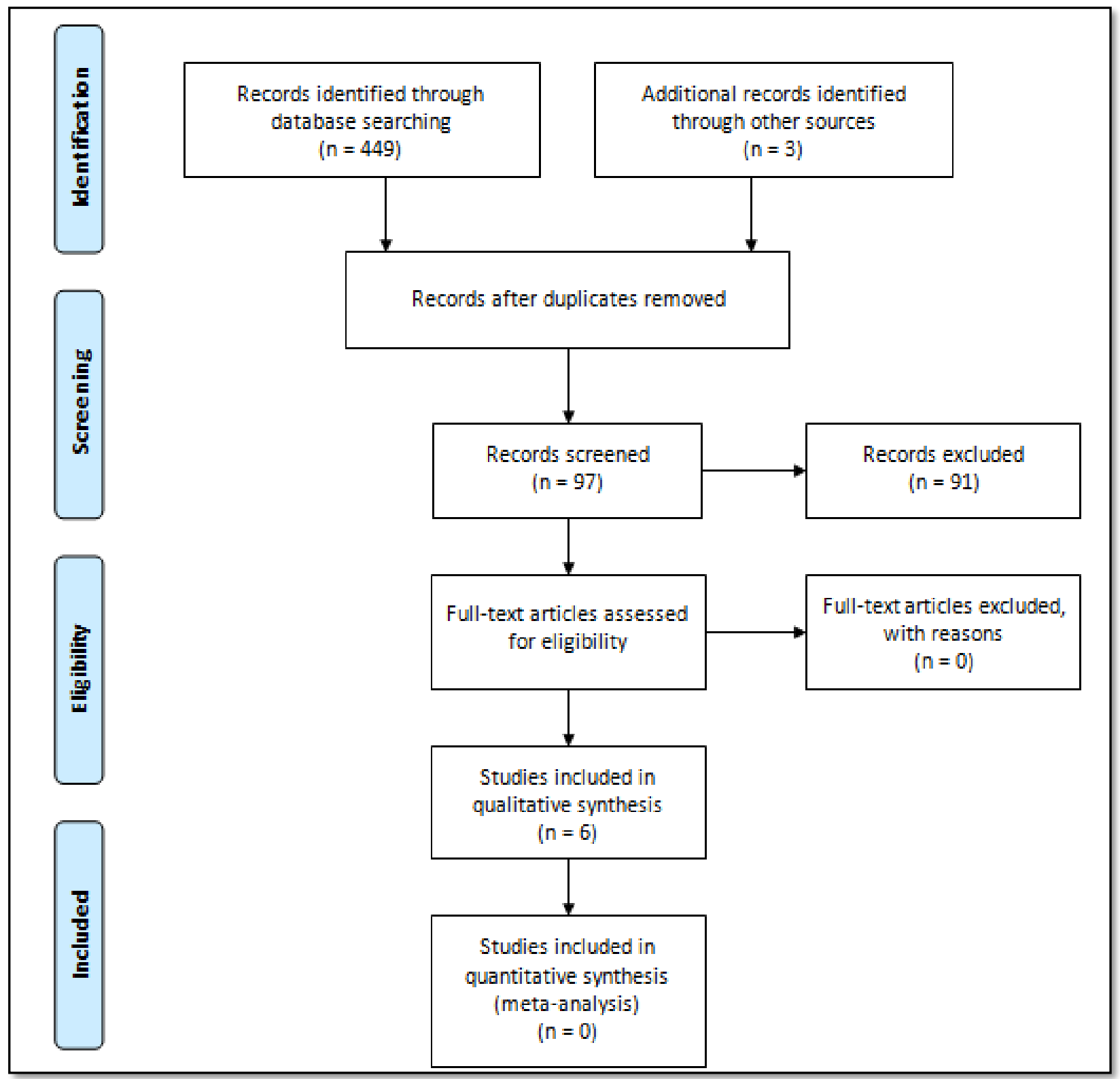

Figure 1: Data collection using PRISMA Protocol 


\section{Findings}

Table 1: List of articles and synthesis reviews

\begin{tabular}{|c|c|c|c|c|c|c|}
\hline No. & Author & Year & Title & $\begin{array}{l}\text { Type of } \\
\text { Research }\end{array}$ & $\begin{array}{l}\text { Research } \\
\text { Objectives }\end{array}$ & Research Findings \\
\hline 1 & $\begin{array}{l}\text { Christy } \\
\text { M. Byrd }\end{array}$ & 2016 & $\begin{array}{l}\text { Does Culturally } \\
\text { Relevant } \\
\text { Teaching Work? } \\
\text { An Examination } \\
\text { From Student } \\
\text { Perspectives }\end{array}$ & $\begin{array}{l}\text { Case } \\
\text { study }\end{array}$ & $\begin{array}{l}\text { - Explore how } \\
\text { the } \\
\text { perceptions of } \\
\text { students about } \\
\text { "Culturally } \\
\text { Relevant" } \\
\text { teaching and } \\
\text { school racial } \\
\text { socialization } \\
\text { are relevant to } \\
\text { the academic } \\
\text { achievement } \\
\text { and students' } \\
\text { attitudes } \\
\text { towards racial } \\
\text { socialization. }\end{array}$ & $\begin{array}{l}\text { - The findings } \\
\text { show that } \\
\text { "Culturally } \\
\text { Relevant" } \\
\text { teaching has a } \\
\text { positive impact } \\
\text { on the daily } \\
\text { teaching and } \\
\text { learning process } \\
\text { of students in } \\
\text { the classroom. }\end{array}$ \\
\hline 2 & $\begin{array}{c}\text { Cholewa } \\
\text { et al. }\end{array}$ & 2014 & $\begin{array}{l}\text { A Qualitative } \\
\text { Examination of } \\
\text { the Impact of } \\
\text { Culturally } \\
\text { Responsive } \\
\text { Educational } \\
\text { Practices on the } \\
\text { Psychological } \\
\text { Well-Being of } \\
\text { Students of } \\
\text { Color }\end{array}$ & $\begin{array}{l}\text { Case } \\
\text { study }\end{array}$ & $\begin{array}{l}\text { - Examine the } \\
\text { "Culturally } \\
\text { Responsive" } \\
\text { education } \\
\text { practices that } \\
\text { can be linked } \\
\text { to the } \\
\text { improvement } \\
\text { of student } \\
\text { psychology. }\end{array}$ & $\begin{array}{l}\text { The results } \\
\text { show that } \\
\text { "Culturally } \\
\text { Responsive } \\
\text { Teaching" which } \\
\text { acts as a } \\
\text { psychological } \\
\text { intervention has } \\
\text { the potential to } \\
\text { promote } \\
\text { academic } \\
\text { achievement of } \\
\text { students. } \\
\text { The } \\
\text { psychological } \\
\text { factors affecting } \\
\text { students } \\
\text { learning where } \\
\text { researchers } \\
\text { suggest that the } \\
\text { use of } \\
\text { "Culturally } \\
\text { Responsive } \\
\text { Teaching" in } \\
\text { learning to } \\
\text { improve } \\
\text { students' } \\
\text { academic }\end{array}$ \\
\hline
\end{tabular}




\begin{tabular}{|c|c|c|c|c|c|c|}
\hline & & & & & & $\begin{array}{l}\text { achievement } \\
\text { directly or } \\
\text { indirectly } \\
\text { through } \\
\text { psychological } \\
\text { well-being that } \\
\text { will lead to } \\
\text { academic } \\
\text { success. }\end{array}$ \\
\hline 3 & $\begin{array}{c}\text { Tyrone } \\
\text { Howard } \\
\& \\
\text { Clarence } \\
\text { L. Terry }\end{array}$ & 2011 & $\begin{array}{l}\text { Culturally } \\
\text { responsive } \\
\text { pedagogy for } \\
\text { African American } \\
\text { students: } \\
\text { promising } \\
\text { programs and } \\
\text { practices for } \\
\text { enhanced } \\
\text { academic } \\
\text { performance }\end{array}$ & $\begin{array}{l}\text { Case } \\
\text { study }\end{array}$ & $\begin{array}{l}\text { Examine } \\
\text { "Culturally } \\
\text { Responsive } \\
\text { Pedagogy" as } \\
\text { an } \\
\text { intervention to } \\
\text { improve the } \\
\text { performance } \\
\text { of African } \\
\text { American } \\
\text { students. }\end{array}$ & $\begin{array}{l}\text { The results } \\
\text { show that the } \\
\text { achievement of } \\
\text { the students, } \\
\text { the rate of } \\
\text { graduation as } \\
\text { well as the rate } \\
\text { of pupils who } \\
\text { further their } \\
\text { learning in } \\
\text { college } \\
\text { increases after } \\
\text { the "Culturally } \\
\text { Responsive } \\
\text { Pedagogy" is } \\
\text { practiced in the } \\
\text { teaching and } \\
\text { learning } \\
\text { process. }\end{array}$ \\
\hline 4 & $\begin{array}{c}\text { Kelley et } \\
\text { al. }\end{array}$ & 2015 & $\begin{array}{c}\text { Culturally } \\
\text { familiar tasks on } \\
\text { reading } \\
\text { performance } \\
\text { and self-efficacy } \\
\text { of culturally and } \\
\text { linguistically } \\
\text { diverse students }\end{array}$ & $\begin{array}{l}\text { Case } \\
\text { study }\end{array}$ & 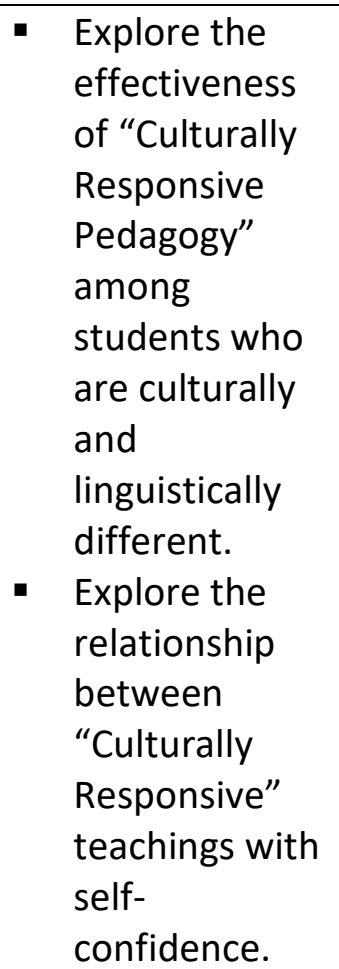 & $\begin{array}{l}\text { - The results } \\
\text { show that the } \\
\text { use of } \\
\text { "Culturally } \\
\text { Responsive } \\
\text { Pedagogy" as a } \\
\text { method of } \\
\text { teaching can } \\
\text { improve reading } \\
\text { achievement as } \\
\text { well as improve } \\
\text { self-reading } \\
\text { among } \\
\text { students. }\end{array}$ \\
\hline
\end{tabular}




\begin{tabular}{|c|c|c|c|c|c|c|}
\hline 5 & $\begin{array}{c}\text { Greg } \\
\text { Wiggan } \\
\& \\
\text { Marcia J. } \\
\text { Watson }\end{array}$ & 2016 & $\begin{array}{l}\text { Teaching the } \\
\text { Whole Child: The } \\
\text { Importance } \\
\text { of Culturally } \\
\text { Responsiveness, } \\
\text { Community } \\
\text { Engagement, } \\
\text { and Character } \\
\text { Development in } \\
\text { High Achieving } \\
\text { African } \\
\text { American } \\
\text { Students }\end{array}$ & $\begin{array}{l}\text { Case } \\
\text { study }\end{array}$ & $\begin{array}{l}\text { Explore the } \\
\text { perceptions of } \\
\text { teachers and } \\
\text { students on } \\
\text { the "Culturally } \\
\text { Responsive } \\
\text { Pedagogy". }\end{array}$ & $\begin{array}{l}\text { - Results show } \\
\text { that } \\
\text { "Multicultural" } \\
\text { curriculum and } \\
\text { "Culturally } \\
\text { Responsive" } \\
\text { education have } \\
\text { positive impacts } \\
\text { on the social, } \\
\text { cultural and } \\
\text { academic } \\
\text { achievement of } \\
\text { students. }\end{array}$ \\
\hline 6 & $\begin{array}{c}\text { Deborah } \\
\text { A. } \\
\text { Harmon }\end{array}$ & 2012 & $\begin{array}{c}\text { Culturally } \\
\text { Responsive } \\
\text { Teaching Though } \\
\text { a Historical } \\
\text { Lens: Will } \\
\text { History Repeat } \\
\text { Itself? }\end{array}$ & $\begin{array}{l}\text { Historical } \\
\text { research }\end{array}$ & $\begin{array}{l}\text { Investigate } \\
\text { and study } \\
\text { "Culturally } \\
\text { Responsive" } \\
\text { teaching } \\
\text { through past } \\
\text { history of } \\
\text { American } \\
\text { education for } \\
\text { African } \\
\text { students. }\end{array}$ & $\begin{array}{l}\text { - Results show } \\
\text { that "Culturally } \\
\text { Responsive } \\
\text { Pedagogy" has } \\
\text { proven its value } \\
\text { and } \\
\text { effectiveness } \\
\text { through past } \\
\text { history. }\end{array}$ \\
\hline
\end{tabular}




\section{Discussion}

To get a comprehensive picture of the impact of "Culturally Responsive Pedagogy" on student academic achievement as well as to understand the current research trends on this subject, research questions are focused on the major findings of research on student learning and academic achievement in relation to "Culturally Responsive Pedagogy".

The results of this study show that "Culturally Responsive Pedagogy" has a positive impact on students' academic learning and achievement. This pedagogy can increase student involvement in learning (Hill 2009; Howard 2001). For example, Byrd's (2016) study proves that "Culturally responsive Pedagogy" approach can improve students' interests, grades, exploration, commitment and self-concept of learning. In short, this approach has a positive impact on student participation in learning besides improve student academic achievement. Not only that, previous research has shown that positive ethnic-racial identity are associated with student academic achievement as well as the students' persistence and this indirectly affects students' academic success. Positive ethnic-racial identity is also capable to reduce discrimination among individuals with different ethnics and racial (Thomas et al. 2009). It is clear that "Culturally Responsive Pedagogy" has a positive impact on the learning of students especially for students that come from various ethnic and racial groups. This should be taken into account as Malaysia is a country of diverse ethnic groups which can get infinite benefits in relation to "Culturally Responsive Pedagogy" as this pedagogy is still new in this country. Hence, more studies relating to this pedagogy are needed to get a more comprehensive picture of the impact of this pedagogy on student learning and academic achievement. In addition, studies related to the readiness of teachers to teach using the "Culturally Responsive pedagogy" are also needed as this directly affects the implementation of this pedagogy in schools which will later affect students' learning. This can be seen when research related to this pedagogy is not conducted in Malaysia. Not only that, studies and research that have been conducted so far only limited to small scale case studies as well as very few or limited (Samuels 2018).

Finally, previous studies have proven the effectiveness of "Culturally responsive Pedagogy" on student learning and academic achievement. However, the number of studies in particular that links this pedagogy to academic achievement is still very few and research involving theoretical framework is indispensable for a clear and holistic description of this pedagogy.

\section{Conclusion}

In conclusion, the "Culturally Responsive" pedagogy is an important way of improving student academic achievement as well as building positive self-identity for students of various ethnic and racial groups. In order to strengthen the implementation of this pedagogy in learning, it is certain that reinforcement should be given to research that describes the practice and its implementation in the classroom as well as its effect on the students. Finally, we need more and comprehensive research including teachers who are proficient in practicing this pedagogy. More studies related to this pedagogy and its impact on students' academic achievement should be carried out as it's contribute to the country that is multiracial especially in the context of education. 
INTERNATIONAL JOURNAL OF ACADEMIC RESEARCH IN BUSINESS AND SOCIAL SCIENCES

Vol. 9, No. 5, May, 2019, E-ISSN: 2222-6990 @ 2019 HRMARS

\section{References}

Byrd, C. M. (2016). Does culturally relevant teaching work? An examination from student perspectives. SAGE Open 6(3), 1-7.

Christianakis, M. (2011). Hybrid texts: Fifth graders, rap music, and writing. Urban Education 46(5), 1131-1168.

Dickson, G. L., Chun, H. \& Fernandez, I. T. (2015). The development and initial validation of the student measure of culturally responsive teaching. Assessment for Effective Intervention 41(3), 141-150.

Gay, G. (2010). Culturally Responsive Teaching: Theory, Research and Practice. Ed. ke-2. New York: Teachers College Press.

Hawley, W. \& Nieto, S. (2010). Another inconvenient truth: Race and ethnicity matter. Educational Leadership 68(3), 66-71.

Hill, M. L. (2009). Wounded healing: Forming a storytelling community in hip-hop lit. Teachers College Record 111(1), 248-293.

Howard, T. C. (2001). Telling their side of the story: African American students' perceptions of culturally relevant teaching. The Urban Review 33(2), 131-149.

Irvine, J. J. (2010). Relevant beyond basics. Teaching Tolerance 36, 40-44.

Rodriguez, J. L., Jones, E. B., Pang, V. O. \& Park, C. D. (2004). Promoting academic achievement and identity development among diverse high school students. High School Journal 87(3), 44-50.

Samuels, A. J. (2018). Exploring culturally responsive pedagogy: Teacher's perspectives on fostering equitable and inclusive classrooms. SRATE Journal 27(1), 22-29.

Silverman, S. K. (2010). What is diversity?: An inquiry into preservice teacher beliefs. American Educational Research Journal 47(2), 292-326.

Sleeter, C. E. (2012). Confronting the marginalization of culturally responsive pedagogy. Urban Education 47(3), 562-579.

Thomas, O. N., Caldwell, C. H., Faison, N. \& Jackson, J. S. (2009). Promoting academic achievement: The role of racial identity in buffering perceptions of teacher discrimination on academic achievement among African American and Caribbean Black adolescents. Journal of Educational Psychology 101, 420-431. 